\title{
MEKANISME KOPING KELUARGA YANG MEMILIKI ANAK RETARDASI
}

\section{MENTAL}

\author{
Muhith Abdul $^{1}$, Veryudha eka ${ }^{2}$, Lasiyati Yuswo Yani ${ }^{3}$, Tria Wahyuningrum ${ }^{4}$, Andita $^{5}$, \\ Tatik S. ${ }^{6}$ \\ ${ }^{1}$ Departeman Keperawatan Sekolah Tinggi Ilmu Kesehatan Majapahit Mojokerto \\ 2,3,4,5 STIKes Bina Sehat PPNI Mojokerto \\ ${ }^{6}$ STIKIP PGRI Pacitan
}

\begin{abstract}
Abstrak
Tanggapan negatif masyarakat tentang anak retardasi mental menimbulkan berbagai reaksi pada orang tua mereka, seperti ada orang tua yang mengucilkan anaknya atau tidak mau mengakui anak yang mengalami retardasi mental. Disisi lain, ada pula orang tua yang berusaha memberikan perhatian lebih dan memberikan yang terbaik kepada anaknya. Mekanisme koping keluarga merupakan cara penyesuaian diri yang digunakan oleh keluarga untuk menghadapi perubahan yang diterima. Tujuan penelitian adalah Menganalisis Mekanisme Koping Keluarga yang memiliki anak Retardasi Mental di Pendidikan Khusus Negeri Seduri kecamatan Mojosari kabupaten mojokerto. Desain penelitian yang digunakan dalam penelitian ini adalah diskriptif yaitu suatu metode penelitian yang dilakukan dengan tujuan utama untuk membuat gambaran tentang suatu keadaan secara objektif. Populasinya seluruh orang tua yang memiliki anak retardasi mental di Pendidikan Khusus Negeri Seduri Mojosari Kabupaten Mojokerto sebanyak 62 orang tua. Sampel sebanyak 62 orang yang diambil dengan total sampling. Variabel pada penelitian ini adalah mekanisme koping keluarga yang memiliki anak retardasi mental. Data di ambil dengan menggunakan kuisioner. Hasil penelitian terhadap 62 responden diperoleh data bahwa sebagian besar responden melaksanakan mekanisme koping adaptif yaitu sebanyak 49 responden (79\%) sedangkan responden yang melaksanakan mekanisme koping mal adaptif hanya 13 responden $(21 \%)$.
\end{abstract}

Kata kunci: Mekanisme koping, keluarga, retardasi mental

\begin{abstract}
Abstrak
About public negative response of children with mental retardation caused varying reactions for their parents, as there parents who exclude their children or do not want to admit children who have mental retardation. On the other hand, there are parents who are trying to give more attention and give the best to the family coping son. mechanism a means of adjustment used by the family to deal with changes that be accepted. aim research is to analyze Coping Mechanisms Families who have children with mental retardation in Education state special districts Seduri district Mojosari mojokerto. Desain research used in this research is descriptive is a method of research conducted with the main objective to create a picture of a situation in objektif. Populations all parents who have children with mental retardation in Special Education state Seduri Mojosari Mojokerto regency as many as 62 parents. Sampel of 62 people who were taken with total sampling. Variabel in this study are coping mechanisms that have a retarded child families mental. Result taken using a study of 62 respondents kuisioner. Data results showed that most of the respondents carry out adaptive coping mechanisms that as many as 49 respondents (79\%), while respondents who implement adaptive coping mechanisms mall only 13 respondents $(21 \%)$.
\end{abstract}

Keyword: Coping mechanisms, family, mental retardation 


\section{PENDAHULUAN}

Tanggapan negatif masyarakat tentang anak retardasi mental menimbulkan berbagai reaksi pada orang tua mereka, seperti ada orang tua yang mengucilkan anaknya atau tidak mau mengakui anak yang mengalami retardasi mental. (Muhith, A., 2015), sisi lain, ada pula orang tua yang berusaha memberikan perhatian lebih dan memberikan yang terbaik kepada anaknya dengan mencari bantuan pada ahli yang dapat menangani anak retardasi mental. Orang tua perlu mekanisme koping dalam mengasuh anak retardasi mental yang berbeda dengan anak lainnya. Mekanisme koping keluarga merupakan cara penyesuaian diri yang digunakan oleh keluarga untuk menghadapi perubahan yang diterima. (Kosasi,E. 2012)

Keterbelakangan mental (Retaldasi Mental, RM) adalah suatu keadaan yang ditandai dengan fungsi kecerdasan umum yang berada dibawah rata-rata disertai dengan berkurangnya kemampuan dibawah rata-rata disertai dengan berkurangnya kemampuan untuk menyesuaikan diri (berperilaku adaptif), yang mulai timbul sebelum usia 18 tahun. (Muhith A., 2015). Orang-orang yang secara mental mengalami keterbelakangan, memiliki perkembangan kecerdasan (intelektual) yang lebih rendah dan mengalami kesulitan dalam proses belajar serta adaptif sosial. 3\% dari jumlah penduduk mengalami keterbelakangan mental.

Mekanisme koping keluarga digunakan untuk mengatasi tuntutan internal dan atau eksternal yang melelahkan atau melebihi sumber individu. Mekanisme koping keluarga merupakan respon yang positif, sesuai dengan masalah, afektif, persepsi, dan respon perilaku yang digunakan keluarga dan sub sistemnya untuk memecahkan suatu masalah atau mengurangi stress yang diakibatkan oleh masalah atau peristiwa (Suri, 2012).

Selain itu diperlukan pola asuh orang tua yang berbeda dengan anak normal lainnya terhadap anak retardasi mental. Sikap yang penuh cinta kasih dan penerimaan terhadap apapun keadaan anak merupakan hal yang dibutuhkan oleh anak. Orang tua merasa bingung dengan keadaan anaknya yang mengalami keterbelakangan mental. Pengasuhan dan perawatan terhadap anak retardasi mental dengan berbagai masalah yang dihadapi dapat memicu terjadinya konflik dalam rumah tangga (Rasmun, 2009).

Menurut WHO, di Amerika 3\% dari penduduknya mengalami keterbelakangan mental, di Belanda 2,6\%, di Inggris 1-8\%, 
dan di Asia $\pm 3 \%$. Diperkirakan di Indonesia 1-3\% dari jumlah penduduk Indonesia menderita retardasi mental, yang berarti dari 1000 penduduk diperkirakan 30 penduduk menderita retardasi mental dengan kriteria retardasi mental ringan $80 \%$, retardasi mental sedang $12 \%$, dan retardasi mental berat $1 \%$. retardasi mental (30.460 anak) Data ini tersebar di seluruh Indonesia dengan proporsi terbanyak di Jawa Tengah, Jawa Timur, dan Jawa Barat Berdasarkan hasil studi pendahuluan pada tanggal 15 desember 2015 melalui teknik wawancara kepada 10 orang tua yang memiliki anak retardasi mental di SLB-C Seduri orang tua mengatakan belum mengetahui tentang mekanisme koping keluarga dan mereka belum tau apakah baik atau buruk. Menurut Kepala sekolah SLB-C seduri, belum pernah dilakukan penilaian mekanisme koping keluarga yang memiliki anak retardasi mental.

Mekanisme koping keluarga sangat di butuhkan dalam merawat atau mendidik anak dengan retardasi mental karena anak retardasi mental sangat membutuhkan perhatian secara khusus apabila mekanisme koping kurang anak akan merasa di kucilkan oleh orang tuanya, selain itu orang tua merasa malu dengan keadaan anaknya. Dampak dari mekanisme koping keluarga yang kurang diantaranya akan menimbulkan gangguan harga diri pada anak dengan retardasi mental. Banyak orang tua yang tidak pedulidengan kondisi anaknya tindakan yang meraka lakukan hanya mensekolakan anaknya di SLB (Rasmun, Skp., 2010).

Upaya yang dapat dilakukan untuk meningkatkan mekanisme koping dalam keluarga yaitu dengan memberitahu dan memberikan pengetahuan mengenai mekanisme koping keluarga dengan anak retardasi mental.

Berdasarkan penjelasan pada latar belakang diatas maka peneliti tertarik untuk melakukan penelitian dengan judul: "Mekanisme koping keluarga yang memiliki anak Retardasi Mental di Pendidikan khusus negeri seduri mojosari”

\section{METODE PENELITIAN}

Desain penelitian yang digunakan dalam penelitian ini adalah diskriptif yaitu suatu metode penelitian yang dilakukan dengan tujuan utama untuk membuat gambaran tentang suatu keadaan secara objektif. Metode penelitian deskriptif digunakan untuk memecahkan atau menjawab permasalahan yang sedang dihadapi pada situasi sekarang.

Populasi pada penelitian ini adalah seluruh orang tua yang memiliki anak retardasi mental di Pendidikan Khusus Negeri 
Seduri Mojosari Kabupaten Mojokerto sebanyak 62 orang tua.

Sampling pada penelitian ini adalah menggunakan total sampling. Teknik total sampling ini digunakan untuk menentukan sampel bila semua anggota populasi menjadi sampel pada penelitian (Muhith, A., Nasir 2011).

Sampel pada penelitian ini adalah seluruh orang tua yang memiliki anak retardasi mental di Pendidikan Khusus Negeri Seduri Mojosari Kabupaten Mojokerto sebanyak 62 orang tua.

Variabel penelitian pada penelitian ini adalah mekanisme koping keluarga yang memiliki anak retardasi mental.

\section{HASIL PENELITIAN DAN PEMBAHASAN}

Karakteristik responden meliputi usia, pendidikan, pekerjaan, jumlah anak ke.

Data tersebut disajikan dalam bentuk frekuensi.

Tabel 1.1 Distribusi Frekuensi mekanisme koping keluarga Berdasarkan Usia.

\begin{tabular}{ccc}
\hline Pendidikan & Frekuensi & Persentase (\%) \\
\hline SD & 11 & $17,8 \%$ \\
SLTP & 21 & $33,9 \%$ \\
SLTA & 27 & $43,6 \%$ \\
PT & 3 & $4,9 \%$ \\
\hline Jumlah & 62 & $100 \%$ \\
\hline
\end{tabular}

Berdasarkan tabel 1.1 dapat diketahui bahwa sebagian besar responden berusia > 35 tahun yaitu sebanyak 39 responden (63
\%). Menurut pendapat (Nursalam, 2013) dengan bertambahnya usia manusia, seseorang akan terjadi perubahan pada aspek fisik dan psikologis (mental). Semakin cukup umur, tingkat kematangan seseorang akan lebih matang dalam berfikir dan bekerja dari masyarakat lebih dewasa akan lebih dipercayai daripada orang yang belum cukup tinggi kedewasaannya. Tidak dapat dipungkiri bahwa semakin bertambahnya usia seseorang semakin mudah pula mereka mengetahui cara melakukan perawatan pada anak, dan pada akhirnya makin banyak pula pengetahuan dan pengalaman yang dimilikinya, sebaliknya jika seseorang kurang dalam melakukan perawatan anaknya dapat berpengaruh besar terhadap mekanisme koping keluarganya sendiri.

Tabel 1.2 Distribusi Frekuensi Mekanisme koping keluarga berdasarkan pendidikan.

\begin{tabular}{ccc}
\hline Usia & Frekuensi & Persentase (\%) \\
\hline$<20$ & 4 & $65 \%$ \\
$20-30$ & 19 & $30,7 \%$ \\
$>35$ & 39 & $63 \%$ \\
\hline Jumlah & 62 & $100 \%$ \\
\hline
\end{tabular}

Berdasarkan tabel 1.2 dapat diketahui bahwa hampir setengah dari responden berpendidikan SLTA sebanyak 27 responden (43,6\%). Menurut (Notoadmodjo, 2011) pendidikan berarti hubungan yang diberikan seseorang pada orang lain terhadap semua hal agar mereka 
dapat memahami. Tidak dapat dipungkiri bahwa semakin tinggi pendidikan seseorang semakin mudah pula mereka menerima informasi, dan pada akhirnya makin banyak pula pengetahuan yang dimilikinya, sebaliknya jika seseorang kurang mendapatkan informasi tentang mekanisme koping keluarga dapat berpengaruh besar terhadap mekanisme koping keluarganya sendiri.

Tabel 1.3 Distribusi Frekuensi Mekanisme koping keluarga berdasarkan Pekerjaan

\begin{tabular}{lcc}
\hline Pekerjaan & Frekuensi & Presentase (\%) \\
\hline Petani & 0 & $0 \%$ \\
Swasta & 24 & $38,8 \%$ \\
Wiraswasta & 15 & $24,2 \%$ \\
PNS & 0 & $0 \%$ \\
Tidak bekerja & 23 & $37,1 \%$ \\
\hline Jumlah & 62 & $100 \%$ \\
\hline
\end{tabular}

Berdasarkan tabel 1.3 dapat diketahui bahwa hampir seluruh responden bekerja sebagai pegawai swasta yaitu sebanyak 24 responden (38,8\%). pekerjaan adalah sekumpulan kedudukan (posisi) yang memiliki persamaan kewajiban atau tugastugas pokoknya. Dalam kegiatan analisis jabatan, satu pekerjaan dapat diduduki oleh satu orang, atau beberapa orang yang tersebar di berbagai tempat. Ada beberapa faktor yang mendukung ibu bekerja adalah karena dihadapkan pada tuntutan hidup yang terlalu tinggi, gaji suaminya tidak mencukupi kebutuhan hidupnya, pendapatan tambahan untuk keleluasaan finansial, para ibu yang ingin mengembangkan bakatnya menjadi komersil, dan juga karena ibu merasa bosan jika harus mengurus anak di rumah, mereka lebih senang jika bisa mempunyai kesibukan dan berkesempatan untuk bercandaria dengan rekan-rekan kerja. Alasan-alasan diatas menjadi dasar terjadinya penghalang fungsi utama seorang ibu, ibu harus menjalankan peran ganda dalam melaksanakan perannya sebagai sosok seorang ibu. Pekerjaan yang terlalu padat akan mempengaruhi fungsinya sebagai orang tua karena waktu yang diberikan tidak maksimal.

Tabel 1.4 Distribusi Frekuensi Mekanisme koping keluarga berdasarkan anak

\begin{tabular}{ccc}
\hline Anak ke & Frekuensi & Persentase (\%) \\
\hline anakke 1 & 15 & $24,2 \%$ \\
Anakke 2-4 & 42 & $67,8 \%$ \\
Anak> 5 & 5 & $8,1 \%$ \\
\hline Jumlah & 62 & $100 \%$
\end{tabular}

Berdasarkan tabel 1.4 dapat diketahui bahwa seluruh responden jumlah anak yang mengalami gangguan yaitu anak ke 2-4 sebanyak 42 responden (67,8\%). Dalam hal ini orang tua sudah pernah merawat anak yang pertama dan meraka mengetahui cara merawat anak meskipun anak yang memiliki kelainan. Selain itu juga apabila orang tua mengalami masalah dengan anak yang mengalami gangguan mereka bisa mengalihkan masalah itu dengan bercanda dengan anak yang pertama. 
Tabel 1.5 Distribusi Frekuensi Mekanisme koping keluarga di SLB Negeri seduri Kecamatan Mojosari kabupaten Mojokerto Mei 2016

\begin{tabular}{ccc}
\hline $\begin{array}{c}\text { Pelaksanaan } \\
\text { mekanisme koping }\end{array}$ & Frekuensi & $\begin{array}{c}\text { Persentase } \\
(\boldsymbol{\%})\end{array}$ \\
\hline Adaptif & 49 & $79 \%$ \\
Mal adptif & 13 & $21 \%$ \\
\hline Jumlah & 62 & $100 \%$ \\
\hline
\end{tabular}

Hasil penelitian yang dilakukan di SLB Negeri Seduri Mojosari Kecamatan Mojosari Kabupaten Mojokerto terhadap 62 responden diperoleh data bahwa sebagian besar responden melaksanakan mekanisme koping adaptif yaitu sebanyak 49 responden $(79 \%)$ sedangkan responden yang melaksanakan mekanisme koping mal adaptif hanya 13 responden $(21 \%)$.

Hasil penelitian ini menunjukkan bahwa pelaksanaan mekanisme koping keluarga sebagian besar adalah adaptif. Dimana para orang tua sadar akan pentingnya mekanisme koping keluarga yang baik dalam perawatan anak retardasi mental. Dari hasil penelitian ini yaitu dalam hal ini orang tua yang melaksanakan mekanisme koping adaptif mereka mampu beradaptasi dengan keadaan anaknya yang sekarang sedangakan orang tua yang melaksanakan mekanisme mal adaptif mereka tidak dapat menyesuaikan keadaan dengan kondisi anak yang sekarang.

Dari hasil penelitian didapatkan seluruh mekanisme koping keluarga adaptif dalam merawat anak retardasi mental. Saat mereka mendapatkan sebuah masalah dalam merawat anaknya mereka mendapatkan dukungan sosial berupa nasehat, dukungan yang diperoleh dari lingkungan sekitar baik dari keluarga ataupun dari orang tua yang memiliki anak retardasi mental lainnya. Para orang tua selalu bertukar pendapat dengan keluarga ataupun orang tua yang memiliki anak retardasi metal lainnya. Sedangkan orang tua yang melaksanakan mekanisme koping mal adaptif mereka tidak pernah mendapatkan dukungan sosial dari keluarga ataupun lingkungan mereka malu atau sedih saat ditanya keadaan anaknya dan saat mendapatkan masalah dengan anaknnya mereka mencoba menyelesaikan sendiri tanpa meminta nasehat atau bantuan dari orang lain. (Muhith, A., 2015).

Selain dukungan sosial yang mereka dapatkan hampir seluruh responden yang melaksanakan mekanisme koping keluarga adaptif adalah orang tua yang memiliki anak retardasi mental kelas 3 sampai kelas 6 sekolah dasar di SLB N Seduri. Karena mereka sudah bisa beradaptasi dengan keadaan anaknya sedangkan orang tua yang melaksanakan mekanisme koping mal adaptif adalah orang tua yang memiliki anak retardasi metal kelas 1 sampai kelas 2 sekolah dasar SLB N 
Seduri,mereka belum mengetahui atau belum dapat beradaptasi dengan keadaan anaknya.

\section{KESIMPULAN DAN SARAN}

\section{Kesimpulan}

Berdasarkan hasil penelitian pada 62 responden dapat disimpulkan bahwa mekanisme koping keluarga yang memiliki anak retardasi mental di SLB Negeri Seduri kecamatan Mojosari kabupaten Mojokerto hampir seluruh responden memiliki mekanisme koping adaptif sebanyak 49 responden $(79 \%)$.

\section{Saran}

1. Diharapkan bagi para orang tua yang memiliki anak retardasi mental mengikuti penyuluhan tentang mekanisme koping keluarga, selalu mencari informasi dan berbagi pengalaman dengan orang tualainnya mengenai cara lain merawat anak dengan gangguan mental yang lain.

2. Diharapkan bagi tenaga kesehatan atau tenaga pendidikan setempat untuk lebih aktif meningkatkan koping keluarga dalam merawat anak yang mengalami gangguan mental. Memberikan motivasi kepada orang tua khususnya yang mekanisme koping keluarganya masih mal'adaptif.

\section{REFERENSI}

Kosasi, E. 2012. Cara Bijak Memahami Anak Berkebutuhan Khusus. Bandung

Marilyn, M friedman. 2010. Keperawatan keluarga teori \& praktik. Edisi 3, Jakarta: EGC

Mardalis. 2010. Metode Penelitian (Suatu Pendekatan Proposal). Edisi 1, Cetakan 12. Jakarta: Bumi Aksara.

Muhith A., Nasir (2011). Konsep Dan Penerapan Metodologi Penelitian kesehatan, Edisi 1. yogyakarta: Penerbit nuha medika.

Muhith A., (2015). Pendidikan keperawatan jiwa, Edisi 1. yogyakarta: CV. Andi

.Notoadmodjo, Soekidjo. 2010. Metodologi Penelitian Kesehatan. Jakarta: Rineka Cipta.

Notoadmodjo, Soekidjo. 2012. Metodologi Penelitian Kesehatan. Jakarta: Rineka Cipta

Pieter, H. Z., \& Lubis, N. L. (2012). Pengantar Psikologi Dalam Keperawatan. Jakarta: Kencana Prenada Media Group.

Rasmun, Skp. 2009. Keperawatan Kesehatan Mental Psikiatri Terintegrasi dengan keluarga. Jakarta: IKAPI

Rasmun, Skp. 2010. Stres, Koping dan Adaptasi, Sagung Seto, Jakarta

Suri, W.D. 2012. Mekanisme koping pada orang tua yang memiliki anak Down Syndrome Di SDLB negeri 10770 Lubuk Pekam Kabupaten Deli Serdang. (online). (http://jurnal.usu.a.id/inde.php/jkh/arti le/view/57/0)diakses28november2015

Safaria, T., \& Saputra, E. N. (2012). Manajemen Emosi. Jakarta: Bumi Aksara. 